\title{
Definition of sinkhole triggers and susceptibility based on hydrogeomorphological analyses
}

\author{
Emanuele Intrieri ${ }^{1}$ (1) $\cdot$ Katia Fontanelli ${ }^{1} \cdot$ Federica Bardi $^{1} \cdot$ Federico Marini $^{1,2} \cdot$ Tommaso Carlà $^{1,2} \cdot$ Veronica Pazzi $^{1}$. \\ Michele Di Filippo ${ }^{3} \cdot$ Riccardo Fanti $^{1}$
}

Received: 24 May 2017 / Accepted: 14 December 2017 / Published online: 21 December 2017

(c) The Author(s) 2017. This article is an open access publication

\begin{abstract}
Sinkholes represent a geological risk that is often underrated, mainly due to its very localized nature. In fact, sinkholes occur only under particular circumstances and typically affect relatively small areas. Despite these characteristics, the difficulty in forecasting the precise location and timing of their sudden collapse creates serious problems for civil protection authorities and urban planners. In this framework, identifying the mechanism and thus the triggering factor of sinkholes is strategically pivotal in developing management plans. The present paper addresses the sinkhole-prone area of Il Piano (Elba Island, Central Italy). The integration of hydrogeological surveys, coupled with a thorough study of historical maps and aerial photographs, suggests that the main triggering factor in this area may not be related to water pumping from the karst aquifer, as initially hypothesized. Instead, sinkholes appear to be caused by ravelling and erosive processes occurring entirely in the sedimentary cover when heavy rainfall induces water overpressure within the superficial aquifer.
\end{abstract}

Keywords Karst $\cdot$ Hydrogeology $\cdot$ Risk management $\cdot$ Sinkholes

\section{Introduction}

Sinkholes are natural or anthropogenic ground collapses that occur due to a synergy of predisposing and triggering factors. The causes of sinkholes are often used in sinkhole classification, although many different classifications exist (Cramer 1941; Beck and Sinclair 1986; White 1988; Williams 2003; Waltham et al. 2005; Gutiérrez et al. 2008; Nisio 2008). Predisposing factors are usually the presence of underground cavities (for example, related to human excavations or to a karst bedrock) under an alluvial cover and in conditions of groundwater circulation; triggering factors usually consist of strong increases in the hydraulic gradient, earthquakes (Snyder et al. 1989; Ferreli et al. 2004), loading (Nisio et al. 2007) and acidic fluid upwelling from

Emanuele Intrieri

emanuele.intrieri@unifi.it

1 Department of Earth Sciences, University of Studies of Florence, via La Pira 4, 50121 Florence, Italy

2 Regional Doctoral School of Earth Sciences, University of Studies of Florence, via La Pira 4, 50121 Florence, Italy

3 Department of Earth Sciences, CNR-IGAG, University of La Sapienza, Piazzale Aldo Moro 5, 00142 Rome, Italy deep fractures or faults (Nisio et al. 2007; Caramanna et al. 2008). Since the coexistence of such features occurs only in specific regions, the risk of sinkholes is usually focused in those areas (called sinkhole-prone areas) but is practically null in other regions, unlike other types of geohazards such as landslides that are much more widespread. The localization of sinkholes is one of the reasons why sinkhole risk awareness is low globally. Sinkhole-prone areas are problematic for urban planning, in part owing to this lack of awareness, in part due to the difficulty in finding the precise boundaries of the area at risk and the exact location of where a sinkhole may occur. For example, modern transportation networks, especially highways and fast train railways, have severe restrictions concerning their route and curvature, and avoiding potentially dangerous areas is a major issue. An inaccurate identification of such areas can result in allowing urbanization over zones at risk or, on the contrary, in considering the entirety of the territory as unsuitable for construction.

Since sinkhole forecasting is not a common practice and still being researched (Nof et al. 2013; Jones and Blom 2014; Intrieri et al. 2015; Lee et al. 2016), only a detailed hydrogeological study, coupled with underground information, can help planners delimit the area at risk and identify the 
possible triggering factors, thus enabling the implementation of risk-reduction policies.

In this paper, the possible causes of the sinkholes occurring at Il Piano (Elba Island, Central Italy), where at least nine events have occurred since 2008, are discussed. A previous study (Intrieri et al. 2015) focused on addressing this issue from a monitoring point of view, but this work did not include a detailed hydrogeological study of the triggers of the events and, in particular, their relationships with the water pumping, the rainfall and the aquifer activity (that is, the scope of the present paper).

In this study, sinkhole research has been developed at different levels. First, a detailed study of historical aerial photographs and maps, supported by field surveys aimed at assessing the current setting of the area, has been carried out in order to identify forms (such as circular lakes) possibly linkable to past sinkholes and to reconstruct the complex evolution of the drainage network, in order to contribute to the understanding of the trigger mechanisms. These investigations, focused on the surface runoff regime, were successively integrated with a detailed hydrogeological analysis for characterizing the aquifers, their interactions and their relations with rainfall and water pumping (Fig. 1). Ground displacement data (provided by satellite and ground-based interferometry; Intrieri et al. 2015) were taken into account but not used for this work.

\section{The case study}

The sinkhole-prone area discussed in this study is located in the NE sector of Elba Island (Central Italy), between the Municipalities of Rio nell'Elba and Rio Marina, and is called Il Piano (The Plain) (Fig. 2).

The Il Piano catchment is characterized by a natural, narrow pass just upstream of the village of Rio Marina. During the Pleistocene and Holocene, continuous oscillations of the sea level caused several cycles of erosion and sedimentation, as proved by the alternation of lacustrine, fluvial and hillslope sediments. These sedimentary layers lie above the bedrock, which consists of the Cavo Formation (metamorphic shale) in the western part of the study area and the Rialbano Breccia (formerly defined as Calcare Cavernoso, that is "cave limestone"; Bortolotti et al. 2001). The latter is a karst limestone formation that constitutes the small reliefs present in this area; the karstic nature of the rock is evidenced by the presence of natural
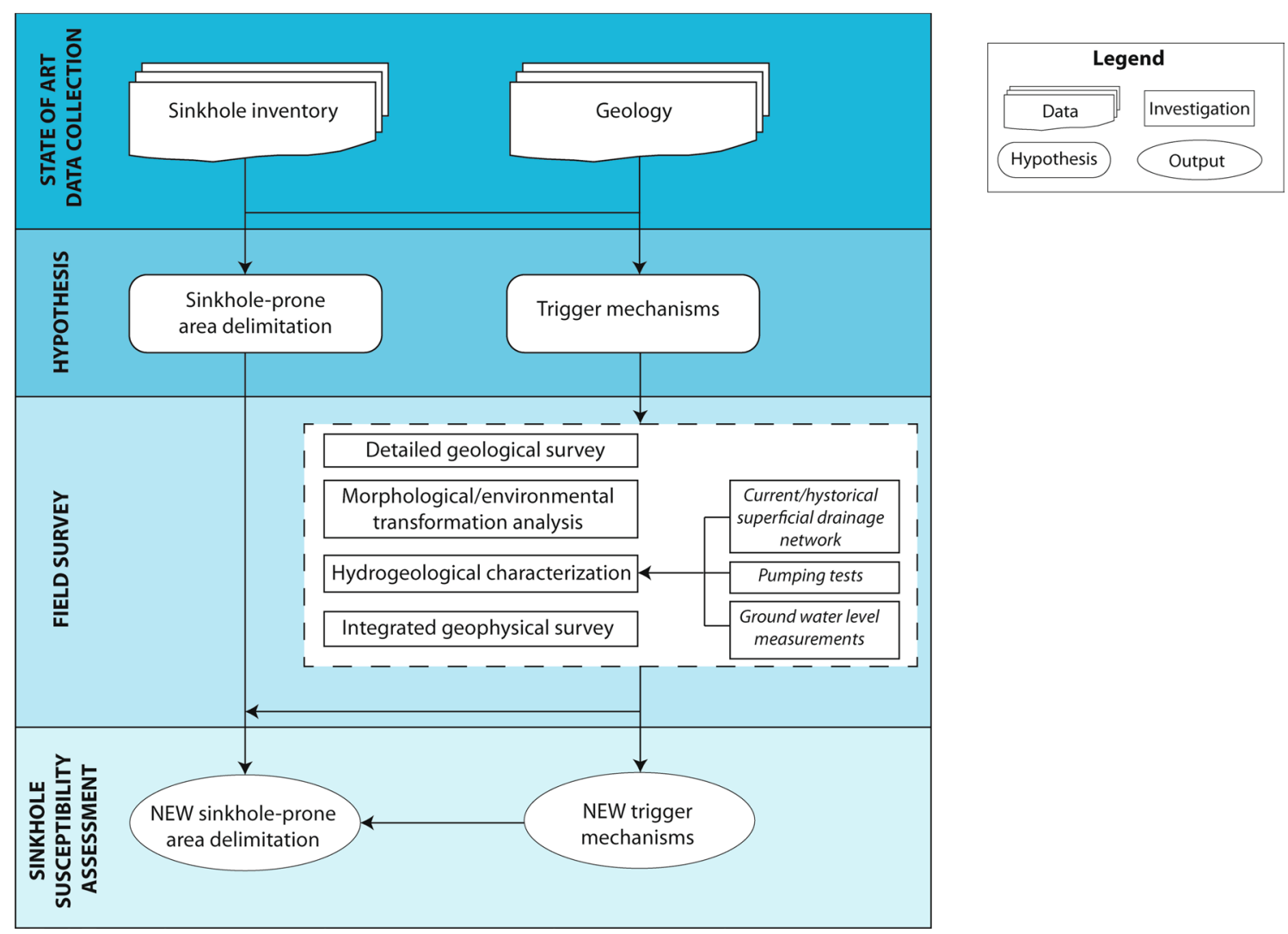

Fig. 1 Flowchart of the integrated geological study carried out in the Il Piano area 


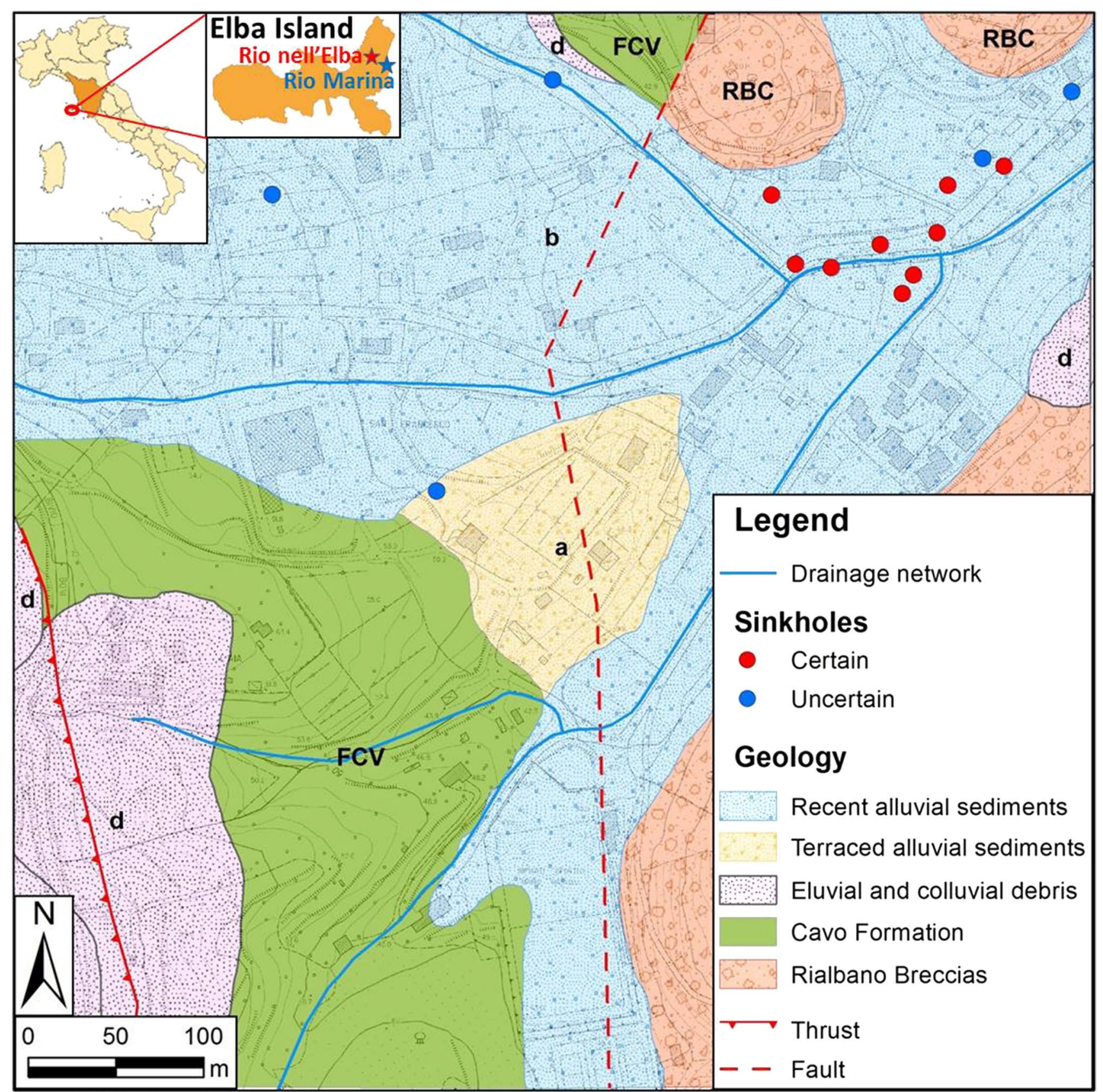

Fig. 2 Geographical and geological framing of the study area. Modified after Bortolotti et al. (2001)

caves, scattered around the eastern part of the island. The Cavo Formation overlays the Rialbano Breccia by means of a tectonic contact.

Drillings and geoelectric studies revealed the high heterogeneity of the alluvial sediments, consisting of predominantly very fine sediments (silt to clay) at the base and coarser sediments shallower (silt to gravel). Within this sedimentary cover (which is approximately 10-30 m thick), lenticular or elongated bodies, constituted by coarse sediments and attributable to recent and ancient riverbeds, are present.
Nine sinkholes have been recorded in the easternmost part of Il Piano (Intrieri et al. 2015), where the Rialbano Breccia are overlaid by the alluvial sediments and are in close proximity to wells used for providing drinking water (Fig. 2). These sinkholes threaten nearby communities and have already severely damaged an important communication route, to the extent that a bypass had to be constructed. Other sinkhole locations, spread to the westernmost sector of the plain, have been noted, although they are considered uncertain, since their presence is based on unconfirmed 
reports by locals. Due to the geomorphological restraints described above, the road going through the pass represents an important route connecting the village of Rio Marina and its port to the rest of the island, which is famous for tourism. In 2013, a sinkhole timely forecasted by Intrieri et al. (2015) led to the disruption of the road pavement and to the construction of a bypass that still passes through an area considered at risk. Additionally, dwellings are included among the elements at risk.

\section{Assessment of the surface runoff}

To address all the possible causes of sinkholes, a study of the drainage system, both natural and artificial, was carried out. The first part of this study focuses on the analysis of historical maps and aerial photographs, to detect possible signs of older sinkholes and to assess the evolution of land use in the Il Piano area. The second part of this study consists of the characterization of the current surface runoff through surveys and discharge measurements.

\section{Historical research}

Milling had occurred in the Il Piano area (which is, in fact, also called Valle dei Mulini, i.e. watermills valley) from the second half of the sixteenth century until the 1950s. The word "Rio" within the name of the towns themselves can be translated as "stream", denoting that a significant water discharge existed in the past but is no longer observable. The presence of 22 watermills in total, as well as millponds and ditches that supplied water for hydraulic energy, is documented (Pierotti 1993), and their ruins are still largely visible (although at different states of conservation). The hydraulic setting during the last two centuries has been reconstructed by analysing historical cartography (French Land Registry, 1802-1803; Grand-ducal Land Registry 1840; topographic map of Elba Island 1895) and aerial photographs (1945, 1954, 1978, 1988, 1990, 1994, 1996, 2012) (Figs. 3, 4). The cartography is derived by CASTORE (2016), the 1945 photograph is from IGM (2016), and the other data are from the Tuscany Region (2016).

This historical analysis does not show the presence of geomorphological features that could be related to the occurrence of previous sinkhole events (for instance, circular or subcircular lakes, depressions, and damp areas). The French Land Registry and Grand-ducal Land Registry (Fig. 3) show the same watermills, millponds and ditches; the slight discrepancies between the two registries are related to the low georeferencing precision of ancient charts. These two charts show the same stream patterns (the Mulini stream originating from the Cinque Bocche spring, Riale stream, San Giuseppe stream, Chiusa stream and Giudimente stream;
Fig. 3) and supply ditch locations for the hydraulic energy mills. In particular, the analysis of the historical cartography has enabled the identification (Fig. 3) of a ditch network for the hydraulic energy supply of the watermills; this network splits from the Mulini stream and flows into the Riale stream.

The 1945 and 1954 aerial photographs show that the drainage system had not changed very much since the drafting of the Grand-ducal Land Registry (Fig. 3); in fact, the ditch network for the hydraulic energy supply of the watermills is still visible in these images. The 1978 aerial photograph testifies to the urbanization of the area with the construction of Togliatti Village, industrial sheds in the Il Piano locality, tubing of the ditches flowing in these areas and enlargement of Provincial Road 26 (Fig. 4). Later aerial photographs show that a well field had been built, and industrial buildings had been constructed (Fig. 4).

\section{Current setting}

Surveys were carried out to assess the actual path of runoff water and to evaluate water infiltration. Discharge measurements were performed at different points of the drainage network on the same day (13 April 2016), after the rainy season. Due to the shallowness of the streams, a current metre could not be used; therefore, measurements were performed by deriving the channel cross-section and by calculating the stream flow velocity from the time required to float a known distance along a regular section of the stream. When possible, the discharge was instead measured with a graduated bucket. In either case, at least 5 measurements were performed, and the average of those measurements was calculated; measurements that clearly deviated from the typical range of the observed values were discarded and not used to compute the average.

Given the high variability in the discharges during the year, the measurements were not aimed at identifying a representative value; instead, they were used to evaluate the percentage of water lost due to infiltration or instead collected within in the upstream drainage basin. Evapotranspiration within the riverbeds is considered negligible given the short length of the streams.

Figure 5 depicts the findings of the survey performed on 13 April 2016, representing intermediate conditions between the dry season and the maximum discharge (wet season). The blue lines indicate those tracts where a flux was observed and measurable, indicating a semi-permanent (i.e. at least seasonal) flux. The green lines are those tracts where flux is present only occasionally, after consistent rainfall. The dashed red lines indicate artificial channels, which in some cases are buried but are still easily detectable because they are marked by belts of reed or visible through open manholes. These channels correspond to those 


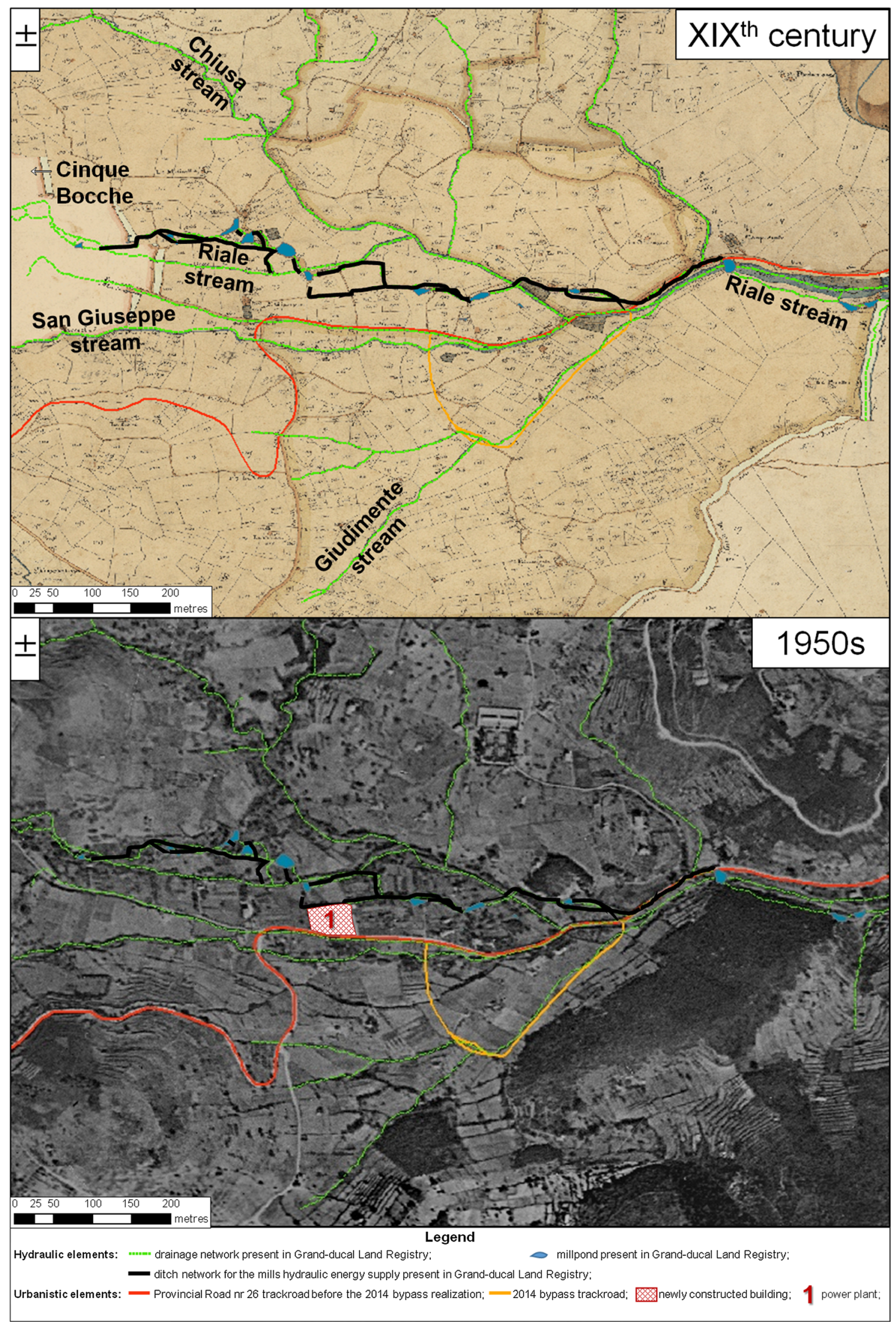

Fig. 3 Evolution of the drainage system and land use shown on the 1840-1841 Grand-ducal Land Registry (top, CASTORE 2016) and on the 1954 aerial photograph (bottom, IGM 2016; Tuscany Region 2016) 


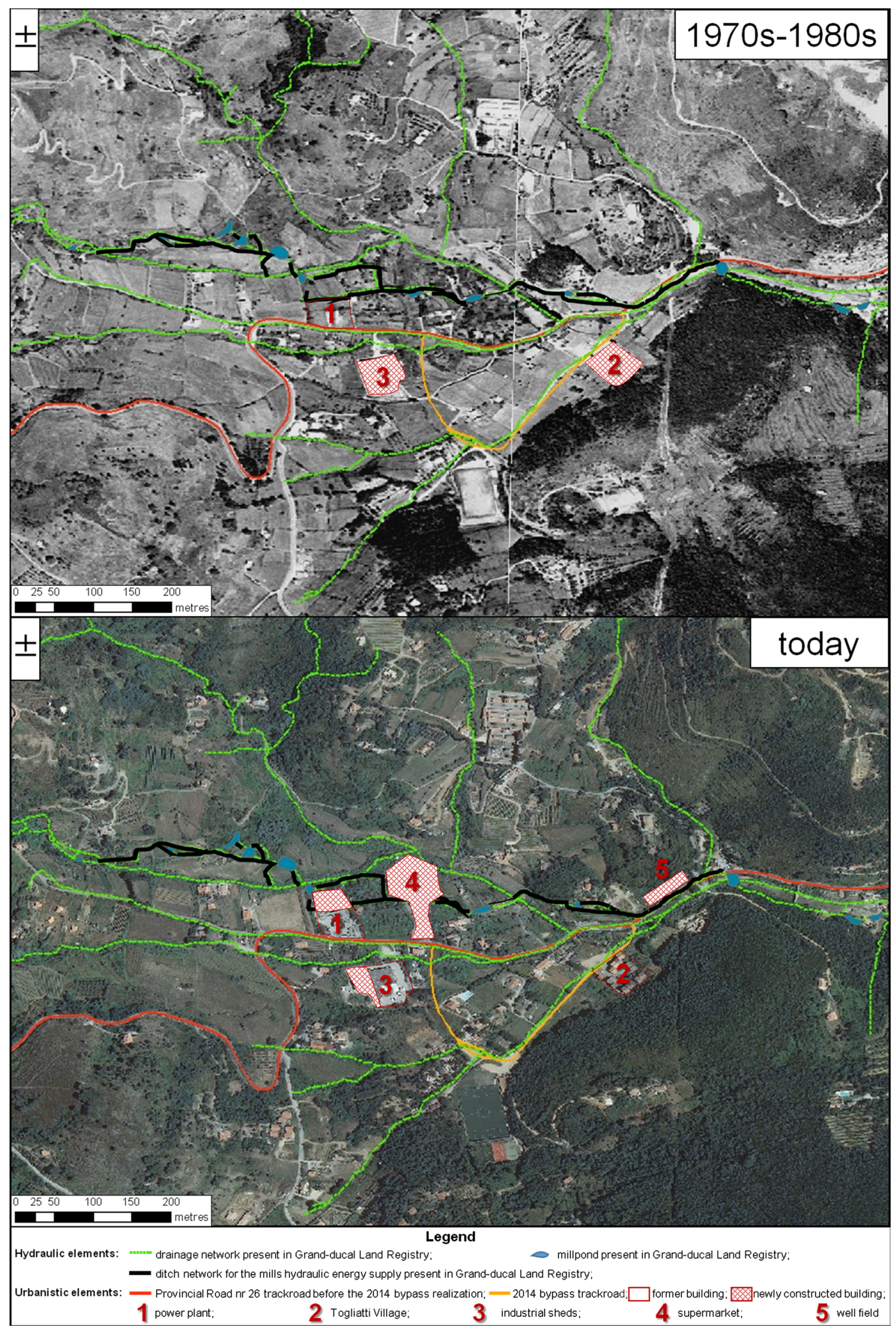

Fig. 4 Evolution of the drainage system and land use shown on the 1978 (top) and 2012 (bottom) aerial photographs (IGM 2016; Tuscany Region 2016) 


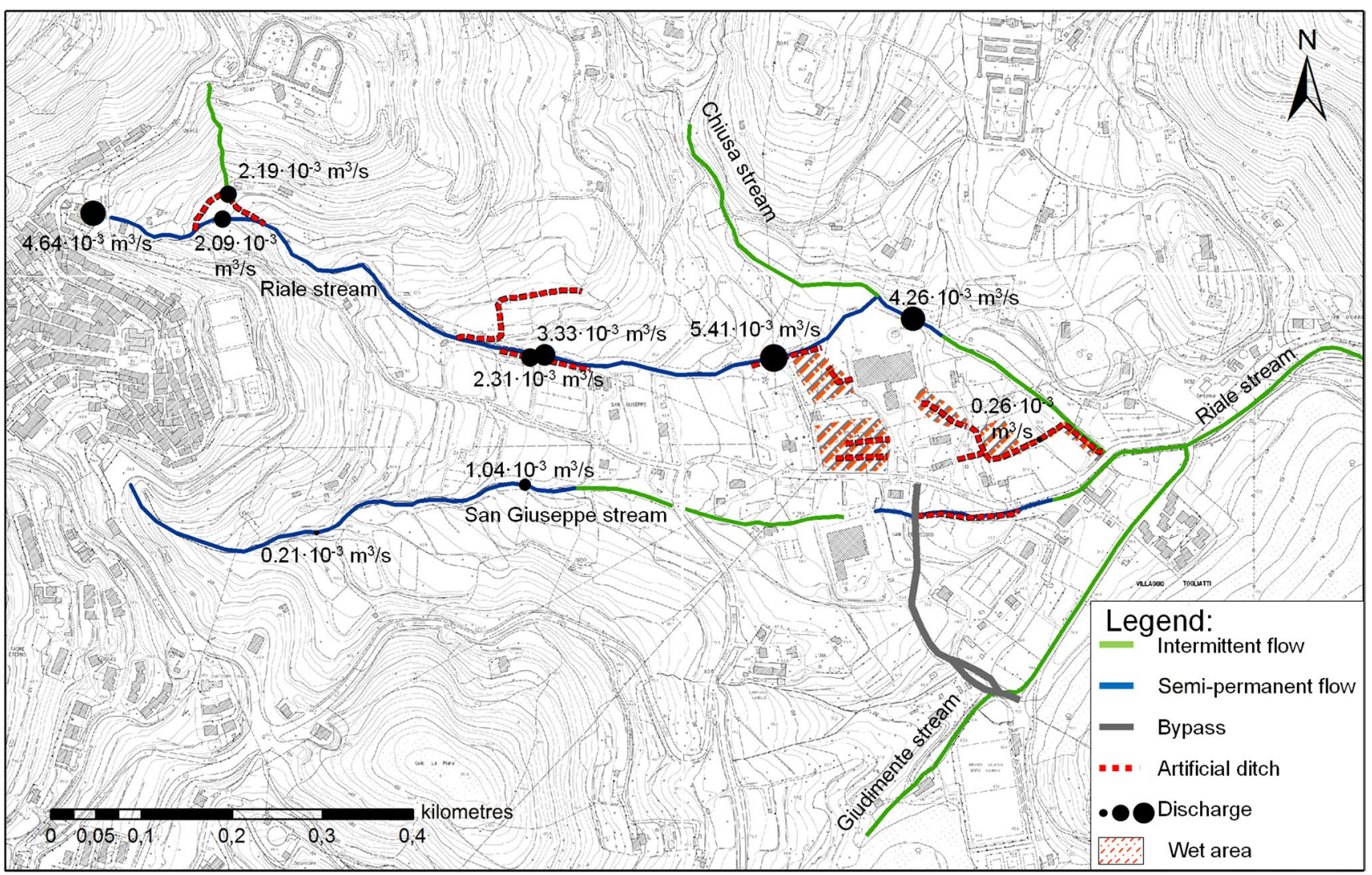

Fig. 5 Map of the discharges measured on 13 April 2016. The diameter of each of the black dots is proportional to the measured discharge at that location

detected through the historical research (Fig. 5) with only a few modern additions, while many tracts are no longer used nor visible. The areas in Fig. 5 filled by orange dashed lines are wet and marshy areas, revealing diffuse infiltration and an ineffective draining; the black dots show where the discharge measurements were performed, and the diameter of the dot is proportional to the measured value.

The flux measured at Cinque Bocche $\left(4.64 \times 10^{-3} \mathrm{~m}^{3} / \mathrm{s}\right.$, Fig. 5) is then diverted into two separate channels: the streambed is deflected by a domestic change to irrigate a vegetable garden (measured discharge of $2.19 \times 10^{-3} \mathrm{~m}^{3} / \mathrm{s}$ ) and then redirected back into the riverbed. Proceeding downstream, other channels or pipes intercept the water that flows parallel to the riverbed. Summing the discharge measured in the riverbed and in the channel at the same location, it is noted that the total discharge does not vary with that measured at Cinque Bocche, but the stream flow measured within the riverbed increases with respect to that measured in the channel. Further downstream, the superficial water flux of the Riale stream ceases to exist (corresponding to the green line), as it quickly infiltrates. This phenomenon does not always occur in the same location; for example, in the spring, it was observed that the point where the stream disappears could change within a few tens of metres. On the other hand, the flux within the channels continues, although with small discharge values (see the small black dot within the red dashed line on the right part of Fig. 5, corresponding to a measured discharge of $0.26 \times 10^{-3} \mathrm{~m}^{3} / \mathrm{s}$ ), until it flows into the Riale riverbed and disappears.

The San Giuseppe stream is characterized by a lower, although increasing, discharge than that of the Riale stream. Interestingly, for a certain tract, the flow disappears and probably continues as hypodermic flow, since it emerges again after a few tens of metres. The water infiltrates definitively further downstream.

For both streams, the water infiltrates in an area where the tectonic contact between the Cavo Formation and Rialbano Breccia occurs, under the sedimentary cover. This observation would indicate that the lithology or man-made buried channels control the surface runoff, as infiltration increases over a more permeable medium. 


\section{Hydrogeological study}

Given the influence of groundwater on sinkhole formation, a detailed hydrogeological study was carried out. This study mainly aimed to accomplish the following:

- acquiring data concerning the variation in the piezometric level, in relation to water pumping and rainfall;

- defining a conceptual hydrogeological model identifying the existing aquifers, their characteristics and interrelations.

\section{Rainfall data}

On 16 October 2015, a meteorological station equipped with a rain gauge, thermometer and anemometer was installed close to well no. 12, within the Rio Marina territory. This meteorological station experienced a few interruptions of activity over a total of 36 days: 22 October 2015, from 30 December 2015 to 27 January 2016, 29 February 2016, 5-8 April 2016 and 11 June 2016. To integrate the missing data, the data from this station were correlated with the precipitation measurements gathered by the rain gauge in Portoferraio (located approximately $10 \mathrm{~km}$ away from the study area).

To this aim, all the rainfall events that occurred in Rio Marina and Portoferraio between 16 October 2015 and 19
June 2016 were identified. For the definition of a rainfall event, a similar approach to that used by Del Ventisette et al. (2012) was adopted. The beginning of an event was defined as a day recording any value higher than $0 \mathrm{~mm}$ of rainfall, and the ending was considered to be when the total precipitation recorded was equal to or lower than $0.2 \mathrm{~mm}$ for at least $48 \mathrm{~h}$. By using this approach, 36 events (corresponding to $432.6 \mathrm{~mm}$ during 107 rainy days) were detected at Portoferraio, while 24 (corresponding to $266.8 \mathrm{~mm}$ during 98 rainy days) were detected at Rio Marina. The rain gauge installed in Portoferraio consistently recorded longer and more intense rainfall than the one in Rio Marina (Fig. 6). Considering only the events in common between the two stations, a ratio between the precipitation measured at Portoferraio and at Rio Marina has been calculated for each event. On average, this ratio is 1.16 . The good correlation between data is proved also by a correlation coefficient $R^{2}$ equal to 0.92 (obtained without considering two outliers, as discussed below).

Some of the days that the Rio Marina rain gauge was not operating occurred during dry periods (as confirmed by the station in Portoferraio). For the remaining days, missing data have been integrated by using the Portoferraio data and assuming a 1.16 ratio. This resulted in a further $89.8 \mathrm{~mm}$ that was added to the Rio Marina dataset and evenly distributed among the days of inactivity.

The comparison between the precipitation measured in Portoferraio and Rio Marina also highlighted the occurrence

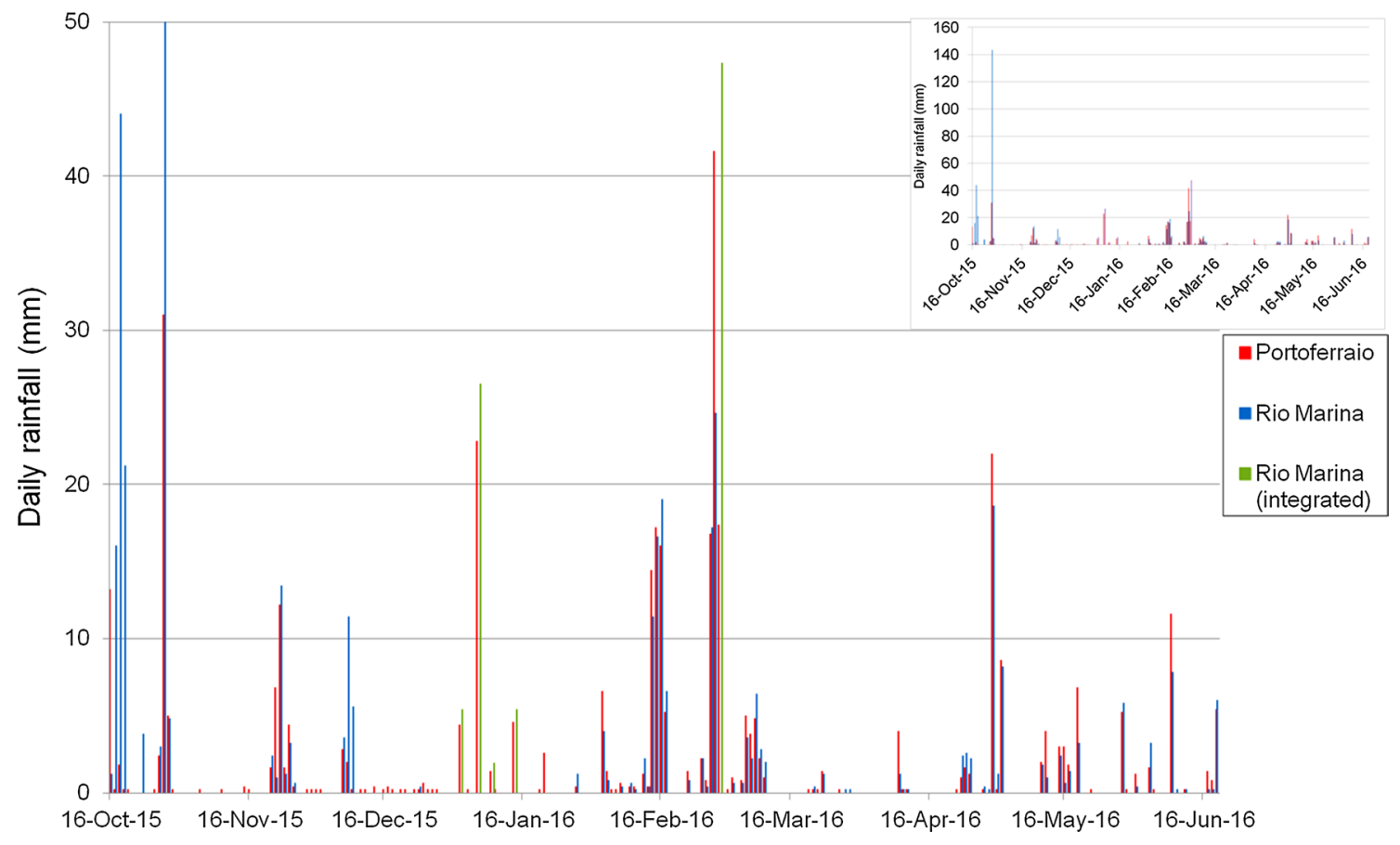

Fig. 6 Daily rainfall measured at the Portoferraio and Rio Marina rain gauges. In the inset graph, the same data with a different scale are reported, in order to include the highest values 
of two particularly interesting events (previously defined as "outliers"), which occurred during the periods 16-19 October 2015 and 27-29 October 2016 in Rio Marina and lasted for one additional day in Portoferraio. The intensities of these two events were, respectively, 82.4 and $151.2 \mathrm{~mm}$ in Rio Marina, while in Portoferraio they were 15.6 and $38.8 \mathrm{~mm}$. Therefore, despite the fact that Rio Marina generally appears to experience slightly less intense precipitation than that at Portoferraio, Rio Marina can suffer from very localized, short and strong rainfall that do not affect Portoferraio.

\section{Piezometric monitoring}

Monitoring consisted of the manual measurement of the water level within all the measurable wells in the Il Piano area (Figs. 7,8 ). In addition, well no. 5 was also automatically monitored through a datalogger (CTD-Diver by Schlumberger Water Services) coupled with a barometer to compensate for the effect of the air pressure (Baro-Diver by Schlumberger Water Services) (Fig. 9).
Based on Fig. 8, the existence of two separate aquifers can be distinguished. The superficial aquifer is identifiable by the water level in well no. 13. Between October 2015 and June 2016, the superficial aquifer displayed little variation (equal to $0.7 \mathrm{~m}$ ). On the other hand, the deeper aquifer showed a maximum variation of $4.5 \mathrm{~m}$. During the days when the wells used for extracting drinking water were not operated, the deeper aquifer reached its maximum piezometric level. The start of pumping from well no. 9 caused a gradual decrease of approximately $1 \mathrm{~m}$, eventually leading to a stable water level.

The piezometric level recorded by the datalogger with an acquisition frequency of $30 \mathrm{~min}$ enabled a comparison of that data with the rainfall data. It can be noted that the groundwater level increase is directly related to the rainfall events (Fig. 9), with a time lag of roughly 3 days.

\section{Characterization of the deeper aquifer}

To assess the features of the deeper aquifer, a pumping test and a recovery test were executed in well no. 12, which

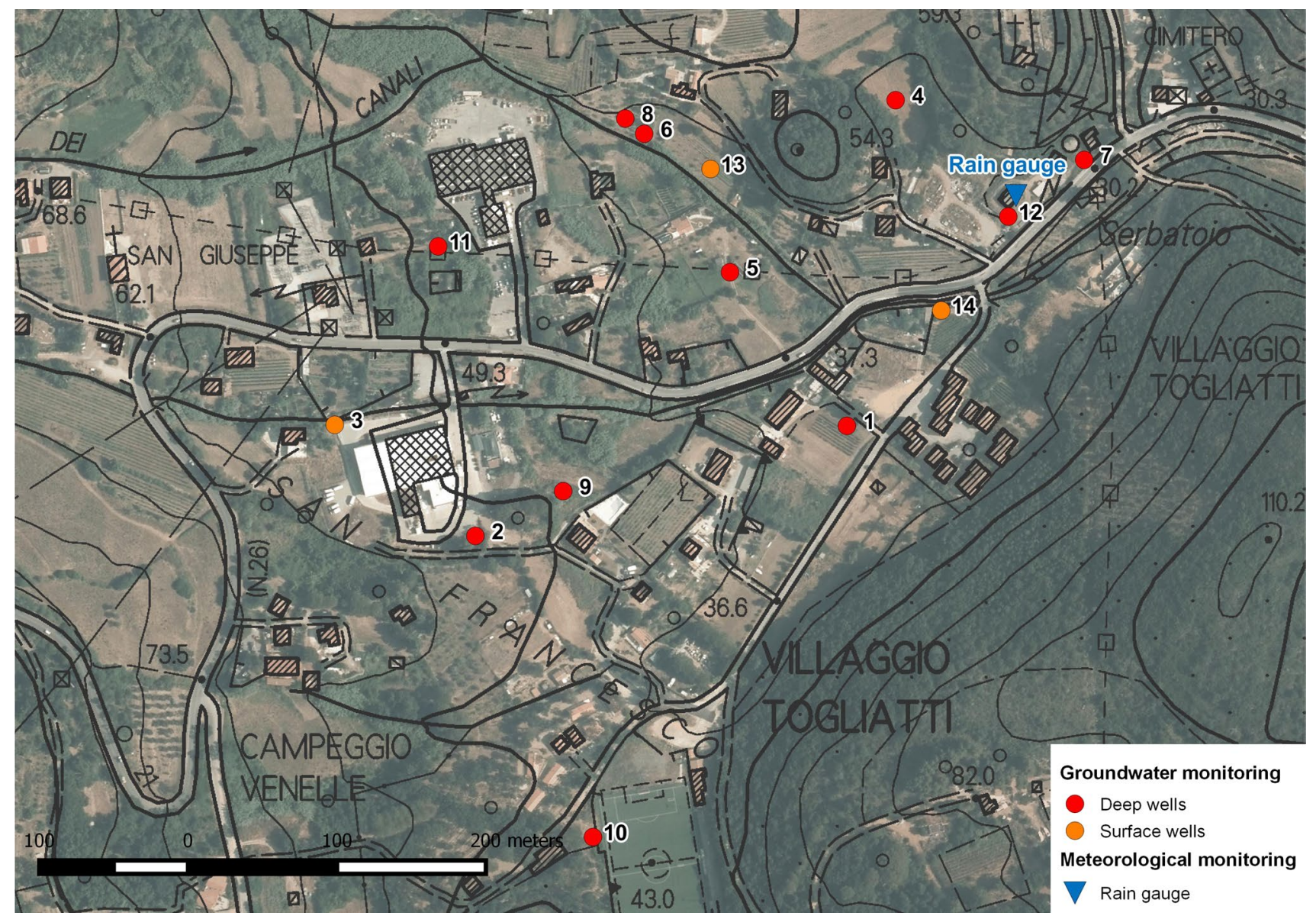

Fig. 7 Location of all the wells in the Il Piano area. The position of the Rio Marina rain gauge is also shown. Wells no. 3 and 14 were dry, while data could not be measured from wells no. 6 and 11 due to accessibility or damage to the well tubing 
A
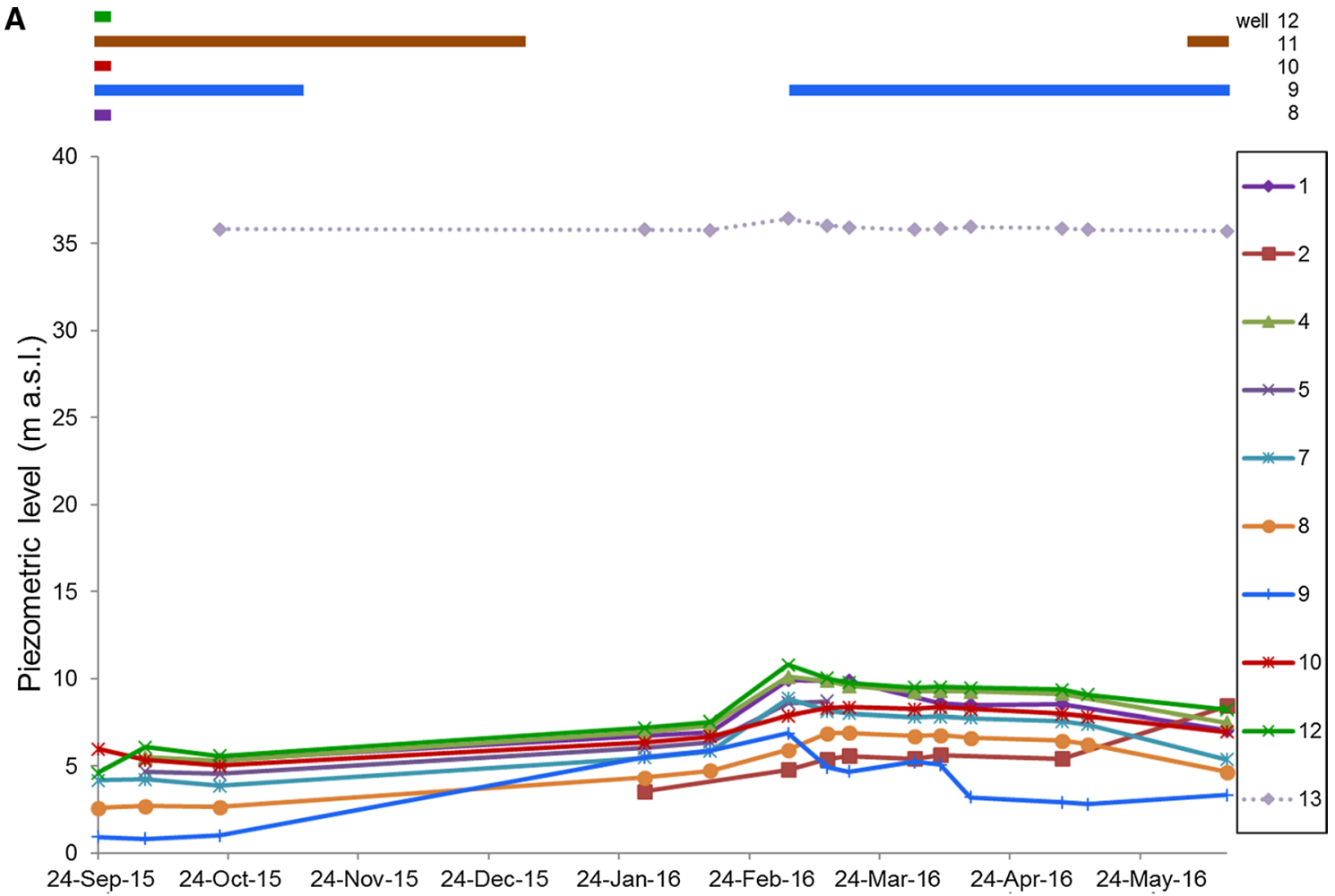

B 140

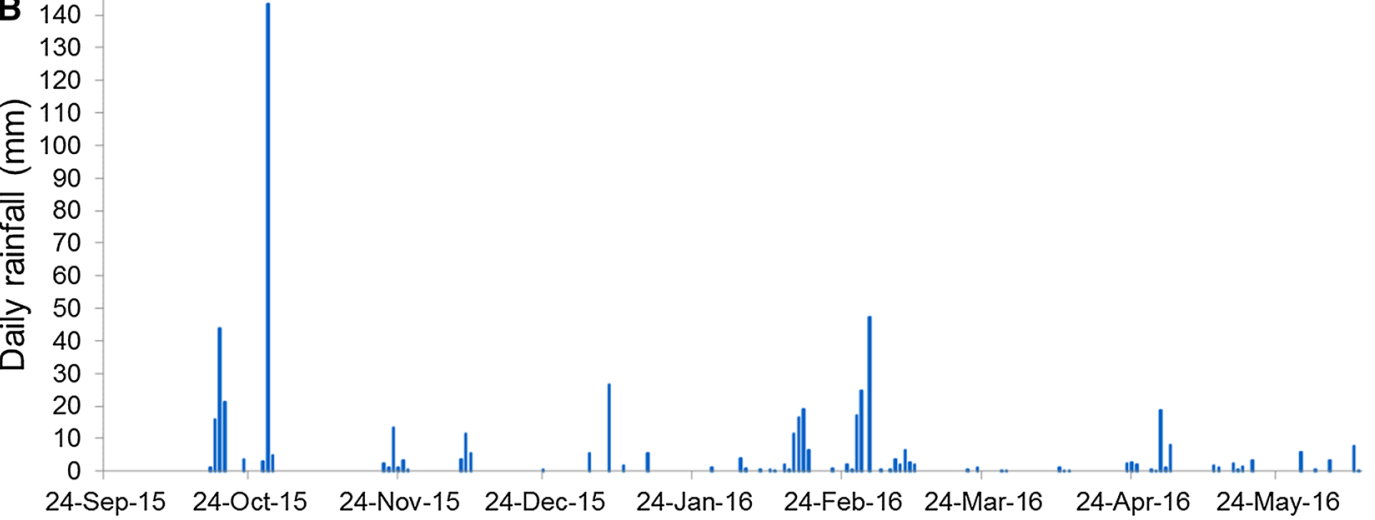

Fig. 8 a Piezometric levels of all the measurable wells in the Il Piano area for the period 24 September 2015-10 June 2016; the numbers indicate the respective wells. The periods when the wells used for drinking purposes were active is indicated at the top of the graph. $\mathbf{b}$
Daily rainfall measured at the Rio Marina rain gauge, integrated as described in the text; note that the measurements started on 16 October 2015 was equipped with a $13 \mathrm{~kW}$ pump placed $65 \mathrm{~m}$ below the wellhead. The test started on 22 October 2015. During the test, the piezometric level was monitored both in well no. 12 and in well no. 7, which was $60 \mathrm{~m}$ to the NE. The stainless steel well tubing is $0.219 \mathrm{~m}$ wide. The filters are placed between -35 and $-47 \mathrm{~m}$ and between -53 and - $59 \mathrm{~m}$ below ground level.

The stratigraphy of the well consists of:

- alluvial sediments (from 0 to $-13 \mathrm{~m}$ ),
- fractured dolomitic limestone (from - 13 to $-55 \mathrm{~m}$, called the Rialbano Breccia), and

- quartz phyllites (from - 55 to - $100 \mathrm{~m}$, called the Verrucano Formation).

The results of the tests are shown in Tables 1 and 2, where $s$ is the lowering of the piezometric level measured in well no. 7 and defined as the difference between the level measured at the beginning of the test and that measured at time $t$. 
Fig. 9 Comparison between the daily rainfall and the piezometric level of well no. 5 measured with the datalogger

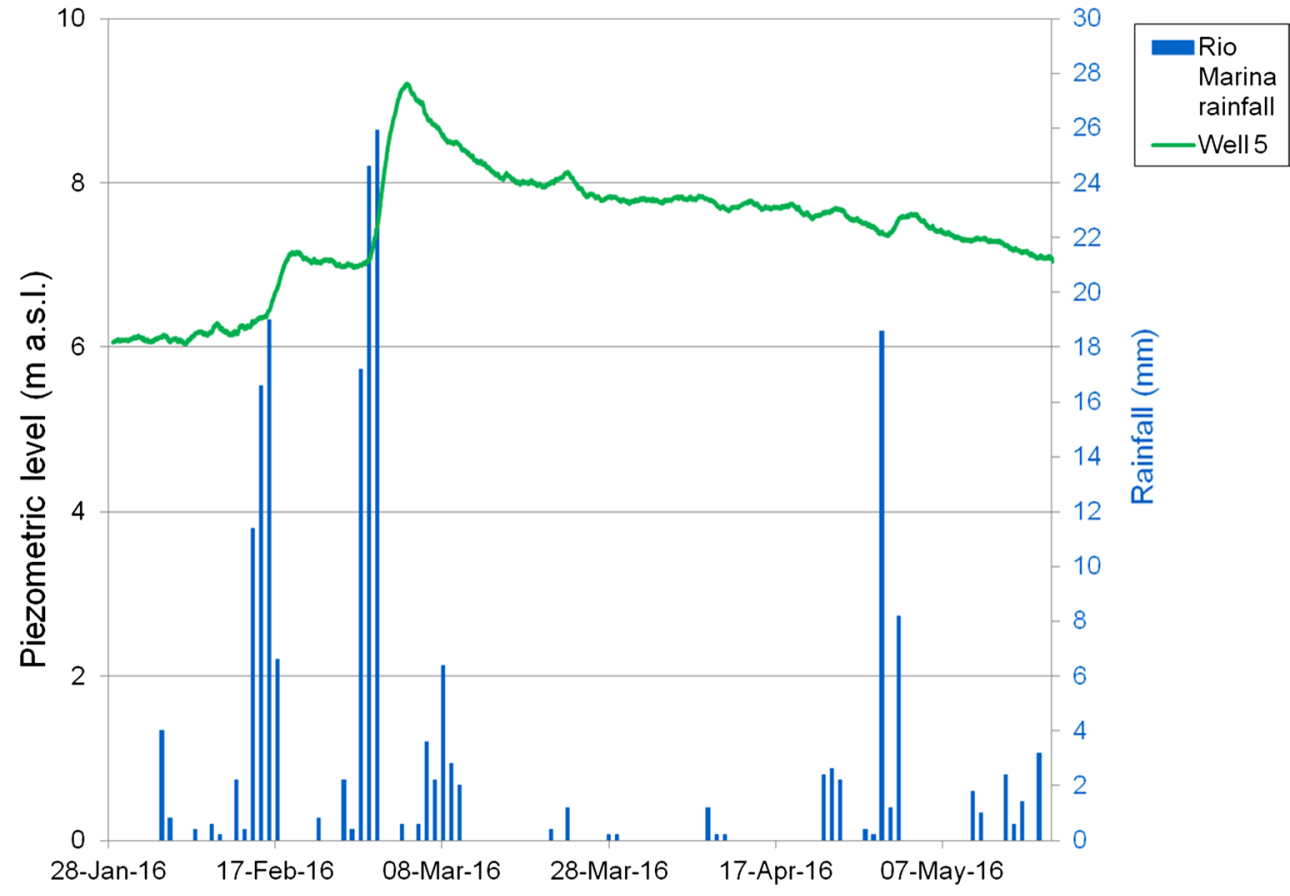

\begin{tabular}{lrrr}
\hline$t(\mathrm{~s})$ & $s(\mathrm{~m})$ & \multicolumn{1}{c}{$t(\mathrm{~s})$} & $s(\mathrm{~m})$ \\
\hline 0 & 0.000 & 1800 & 0.160 \\
120 & 0.020 & 3000 & 0.240 \\
240 & 0.040 & 6000 & 0.270 \\
480 & 0.060 & 10,800 & 0.360 \\
900 & 0.090 & 70,500 & 0.660 \\
\hline
\end{tabular}

Table 1 Lowering values $(s)$ of the piezometric level measured at time $t$ during the pumping test

\section{Geophysical characterization}

Non-invasive high-resolution geophysical methods are commonly accepted as the best approach to identify and map local subsurface heterogeneities such as sinkholes (Butler 1984; Piro et al. 2001; Ezersky 2008; Cardarelli et al. 2014; Giampaolo et al. 2016). Natural cavities, in fact, may be filled with water, air or collapsed/unconsolidated material and therefore provide distinct geophysical contrasts. Selecting the appropriate geophysical methods depends on the main parameters of interest (e.g. depth of investigation, resolution, or diagnostic capability), on the consideration of a number of intrinsic limitations and ambiguities and on the cost-to-time ratio (Ezersky 2008; Cardarelli et al. 2014; Pazzi et al. 2016, 2017a). To characterize the study area and delineate the Il Piano sinkhole-prone area, the following activities were performed (Fig. 10): (a) a microgravity survey with 964 measurements to detect subsuperficial caves (Butler 1984; Bishop et al. 1997; Argentieri et al. 2015; Di Nezza et al. 2015) in primarily the inhabited areas and the ground along the two main roadways; (b) 8 2D electrical tomographies (2D-ERT) and 13 3D-ERT to characterize the heterogeneity of the sediments and to derive the geometry of the aquifers and/or aquicludes (Giampaolo et al. 2016; Pazzi et al. 2016); and (c) 120 single-station seismic noise measurements (H/V technique) to gain insight into the thickness of the alluvial sediment cover (Lane et al. 2008; Lotti et al. 2015; Del Soldato et al. 2016; Pazzi et al. 2017b). The geophysical measurements were calibrated with respect to the subsoil data obtained from the borehole logs collected along the SP26 road after the 2013 sinkhole. 


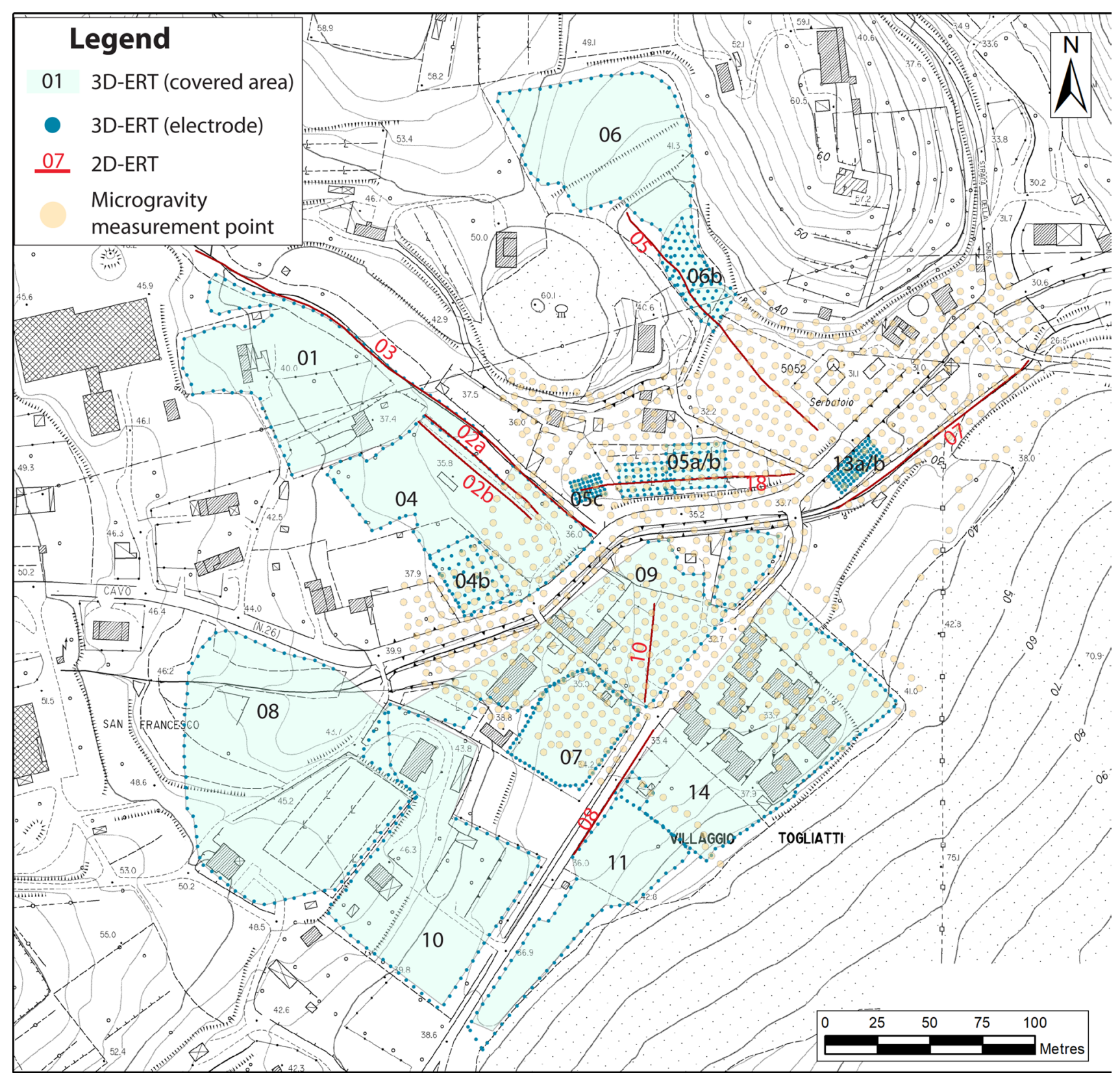

Fig. 10 Location of the geophysical surveys at Il Piano: microgravity measurements (orange dots), 2D-ERT (red lines) and 3D-ERT (light blue dots mark the location of the electrodes, while the light green areas delimit the extension of the areas effectively investigated)

A LaCoste \& Romberg model D gravimeter (sensitivity of $5 \mu \mathrm{Gal}$ ) was used for the microgravity survey in the study area. The gravity was estimated relative to the gravity of the Santa Barbara church in the village of Rio Marina and to altitude measurements by the IGM (Italian Military Geographic Institute) at benchmark no. 126902 at the San Pietro church in Rio nell'Elba. The Bouguer gravity anomaly was calculated with both the polynomial fitting approach and Griffin's technique (1949). The 2D- and 3D-ERTs were collected by means of a SyscalPro georesistivimeter (IRIS Instrument) with a pole-dipole array (min electrode spacing:
$1 \mathrm{~m}$; max electrode spacing: $5 \mathrm{~m}$ ). ERT inversions were performed by the commercial software ErtLab (Geostudi Astier srl, Multi-Phase Technologies LLC). The single-station seismic noise measurements were collected by means of five Tromino: each acquisition ran for $30 \mathrm{~min}$ at $256 \mathrm{~Hz}$, and the data were elaborated according to the SESAME (2004) standard by the commercial software Grilla (Pazzi et al. 2017a, b).

The results (Fig. 11) showed that the main negative microgravity anomalies in the study area are located in sectors affected by collapse (white dots in Fig. 11). The whole 


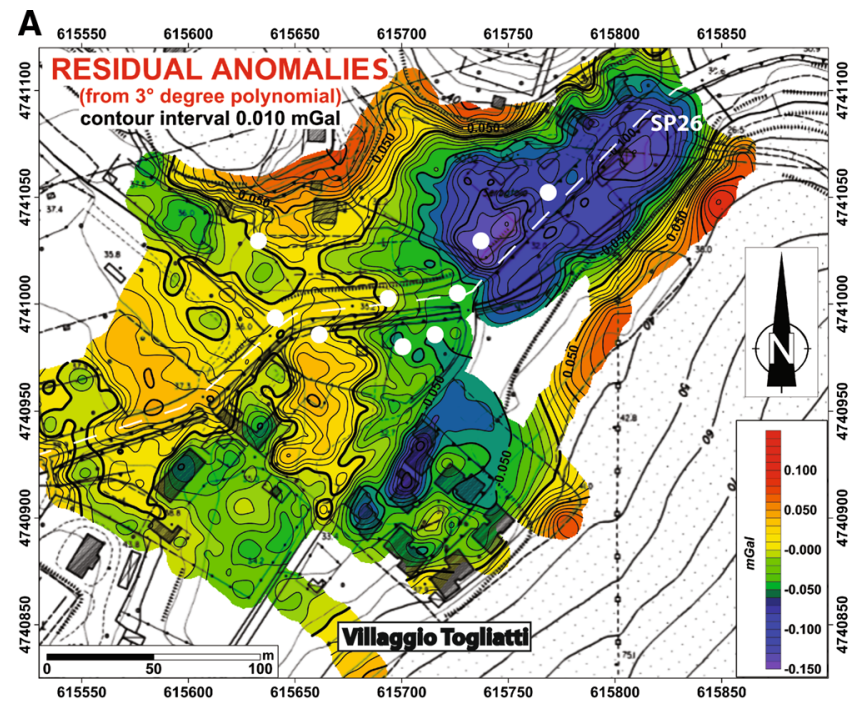

Fig. 11 a Residual anomalies (mGal) calculated by a third-order polynomial fitting. The white dashed line is the SP26, while the white dots are the sinkholes reported in the literature. b $2 \mathrm{D}$ slice of the

area is characterized by a generally increasing trend in negative anomalies from the SW to the NE, with a spatial distribution that suggests a complex geological setting. These negative anomalies could be associated with the presence of lenticular gravel and sand bodies within a sandy silt matrix, highlighted by the ERT results as non-homogeneous highand low-resistivity anomalies. Finally, the geoelectric investigation of the subsurface confirmed that the area has a mean resistivity value within the resistivity range of the Quaternary alluvial deposits, and the $\mathrm{H} / \mathrm{V}$ measurements indicated that the thickness of the valley replenishment material is between 10.5 and $35 \mathrm{~m}$. The ERT results also permit the delimitation of the gravel and sand bodies in the SW portion of the area surveyed by microgravity; in this area, the positive anomalies are probably caused by the road.

In conclusion, the integrated geophysical surveys showed that the anomalies, interpreted as gravel and sand bodies, (a) are mainly located along or on riverbeds, or where the mill pools used to be located, (b) are connected to each other by persistent channels and (c) are in agreement with the hydraulic system of the original natural waterways; furthermore, (d) the younger streams are superimposed on an older hydrological system, which has been covered by anthropogenic activity.

\section{Discussion of the results}

Within a few metres of the superficial sedimentary cover, an unconfined aquifer exists and has been scarcely exploited. The groundwater level is at a shallow depth and

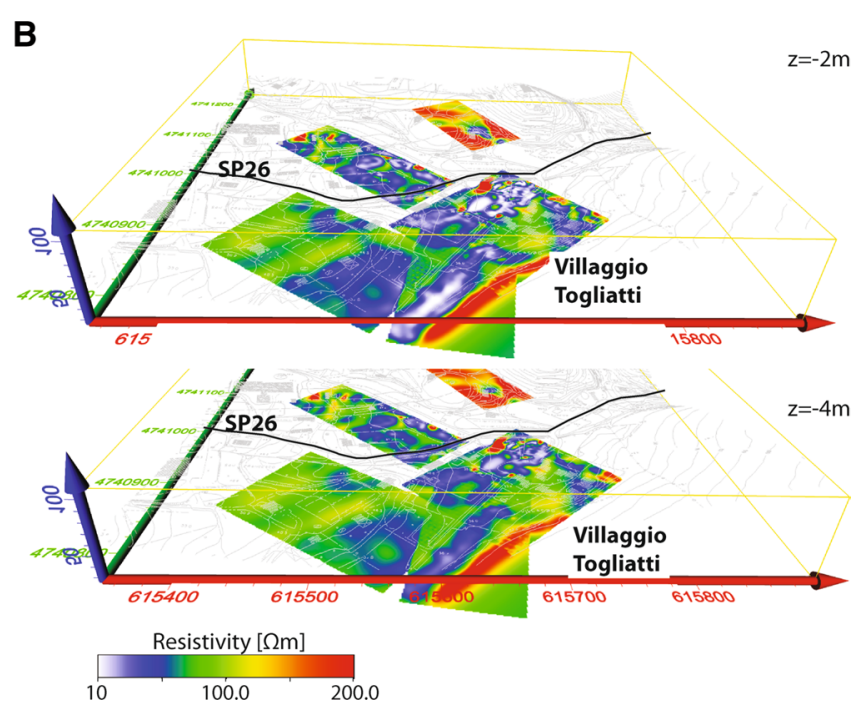

geoelectric results at different depths below ground level ( -2 and $-4 \mathrm{~m})$. The black line is the SP26

is affected by limited oscillations. The lower bound of the aquifer is clay, as evidenced by drillings.

A deeper unconfined aquifer is located within the Rialbano Breccia and is characterized by secondary porosity caused by karst processes, possibly favoured by acidic water (given the presence of pyrite mines on the hills bordering the Il Piano area). This aquifer is largely exploited for drinking water. The pumping activity and rainfall produce moderate variations in the groundwater level (Figs. 8, 9 ); this implies a large extension of this aquifer, probably reaching outside of the Il Piano area and catchment basin. The average depth of this groundwater table is approximately $30 \mathrm{~m}$, which is deeper than the top of the Rialbano Breccia formation, which is therefore not saturated. As a result, it is inferred that the two aquifers do not communicate; this inference was confirmed by the monitoring of the water levels (Fig. 8), showing that the superficial water table is not affected by the oscillations (both caused by natural or anthropic factors) experienced by the deeper one. Therefore, the sinkholes that formed were not deep enough to reach the bedrock (as confirmed by observation) and interconnect the aquifers.

Despite the presence of a karst bedrock and active water pumping activities, the abovementioned observations suggest that the events occurred in Il Piano area may not be attributed to cover collapse sinkholes (that is, sinkholes caused by underground cavities and triggered by water pumping that induced piping in the sedimentary cover). In fact, although this mechanism surely cannot be completely excluded, the independence between the two aquifers suggests, in this case, that a different process might occur 
entirely within the sedimentary cover and produce ravelling sinkholes, as explained in detail below.

Concerning the surface runoff, the surveys evidenced the presence of several ephemeral or intermittent streams, and in particular, of water flowing subsuperficially or infiltrating and then emerging again in a channelized or diffuse fashion. Such a condition is partially due to a drainage network that has been complicated by an intricate system of artificial channels and millponds (partially underground), created to serve 22 mills gathered in a small area (Pierotti 1993). These structures have been gradually abandoned over the last 150 years, especially since the second half of the twentieth century, causing the concealment, damage or obliteration of the existing system and a disorganized evolution and alteration of the drainage network owing to the rapid growth of infrastructures and industrial facilities and to the uncontrolled water diversions for domestic purposes (Figs. 3, 5).

The presence of buried channels contributes to the underground heterogeneity of ancient riverbeds and different sedimentary bodies, characterized by different permeabilities, that were detected through drillings and geophysical investigation. Therefore, the observed infiltration phenomena are likely to occur within these natural bodies and old channels. Although this infiltration may not have consequences during dry periods, it may cause a turbulent (and, in some cases, pressurized) flow in response to strong rainfall events, which have been observed in the area (Fig. 6). This process may cause erosion and piping entirely within the sedimentary cover, possibly leading to the eventual formation of small cavities, similar to that explained by Higgins and Schoner (1993) and Strini (2004). Higgins and Schoner (1993), in particular, described the formation of 2-3-m-wide sinkholes resulting from piping in silty clay fans laced with intersecting strings of permeable sand and gravel. These sand and gravel strings are surrounded by less permeable sediments that are cohesive enough to maintain the pipe walls but are also capable of dispersing into separate grains that the inflow can entrain and remove (Dunne 1990). Interestingly, these processes occur in a region where piping never exists.

In the case of the Il Piano area, discharge and disposal of the entrained sediment may occur within the loose, coarse sediment bodies (Marr 1955; Higgins and Schoner 1993), cracks, riverbeds and buried channels or karst cavities of the Rialbano Breccia, which, in this case, would play only a passive role in the formation of sinkholes.

In this framework, the most susceptible areas are those where permeable underground bodies experience a relatively fast water flow, favoured by the extension of the drained area that may induce possible overpressure. Therefore, Il Piano has been subdivided into smaller catchments (Fig. 12). The northern basins drain a much larger area. All the ascertained (and two uncertain) sinkholes occurred within subbasins $\mathrm{E}$ and $\mathrm{F}$, and 3 unconfirmed sinkholes occurred within subbasins D and $\mathrm{H}$. These areas drain the largest part of the total catchment area of Il Piano. This model explains why the southern part of the region (which drains only subbasins I and L) has not been affected by sinkholes yet, despite the presence of active wells and buried riverbeds (for example those related to the Giudimente stream, see Fig. 5). The same reasoning can be applied to explain why the upstream areas of the plain are also unaffected by such events, which are instead all located within a relatively small portion of the territory (areas H, F, E), where the drained water converges into a narrow section.

To interpret the trigger of the sinkhole phenomena at Il Piano and to delimit and characterize the sinkhole-prone areas into zones (Fig. 13), (a) the 3D spatial distribution of the microgravity and electrical anomalies, (b) the hydrogeomorphological data derived from water level monitoring and (c) an accurate historical reconstruction of the urban and environmental development in the area were integrated. This led to the definition of four zones (light yellow, yellow, orange and red) characterized by increasing susceptibility to sinkholes.

As shown in Fig. 12, the whole hydrographic basin has been divided in subbasins, and without taking into account the deeper groundwater flows, the northern portion of Il Piano (subbasins A-H) collects $79.9 \%$ of the superficial and subsuperficial water, while the southern part collects only $20.1 \%$.

This information has been transposed into a susceptibility map (Fig. 11) and is the reason why the northern part of the area is generally characterized by a higher susceptibility (orange or red). The precise shapes of the coloured areas are drawn following critical lithologic bodies that have been traced from the microgravimetry and geoelectric surveys and the reconstruction of old riverbeds or manmade buried channels. For example, in the southern part of the map (generally characterized by lower susceptibility), the areas with relatively higher susceptibility (yellow) correspond to the Giudimente stream (identified through the surface runoff and historical analyses and then precisely delimited thanks to the geoelectric surveys; see Figs. 3, 5,11 ), where permeable sediments allow faster underground water flow, which can trigger ravelling processes. The identification of this buried riverbed (red area in the geoelectric tomography of Fig. 11) permitted the calibration of the interpretation of the geoelectric surveys and determination of the localization of other bodies across the site that were then mapped. In the northern portion of the map, where the microgravimetric measurements were focused, the delimitation of the most susceptible areas followed an intersection between areas with negative gravity anomalies (indicating possible voids or less compacted sediments; see green and blue areas in Fig. 11) and permeable bodies, such as natural or man-made channels 


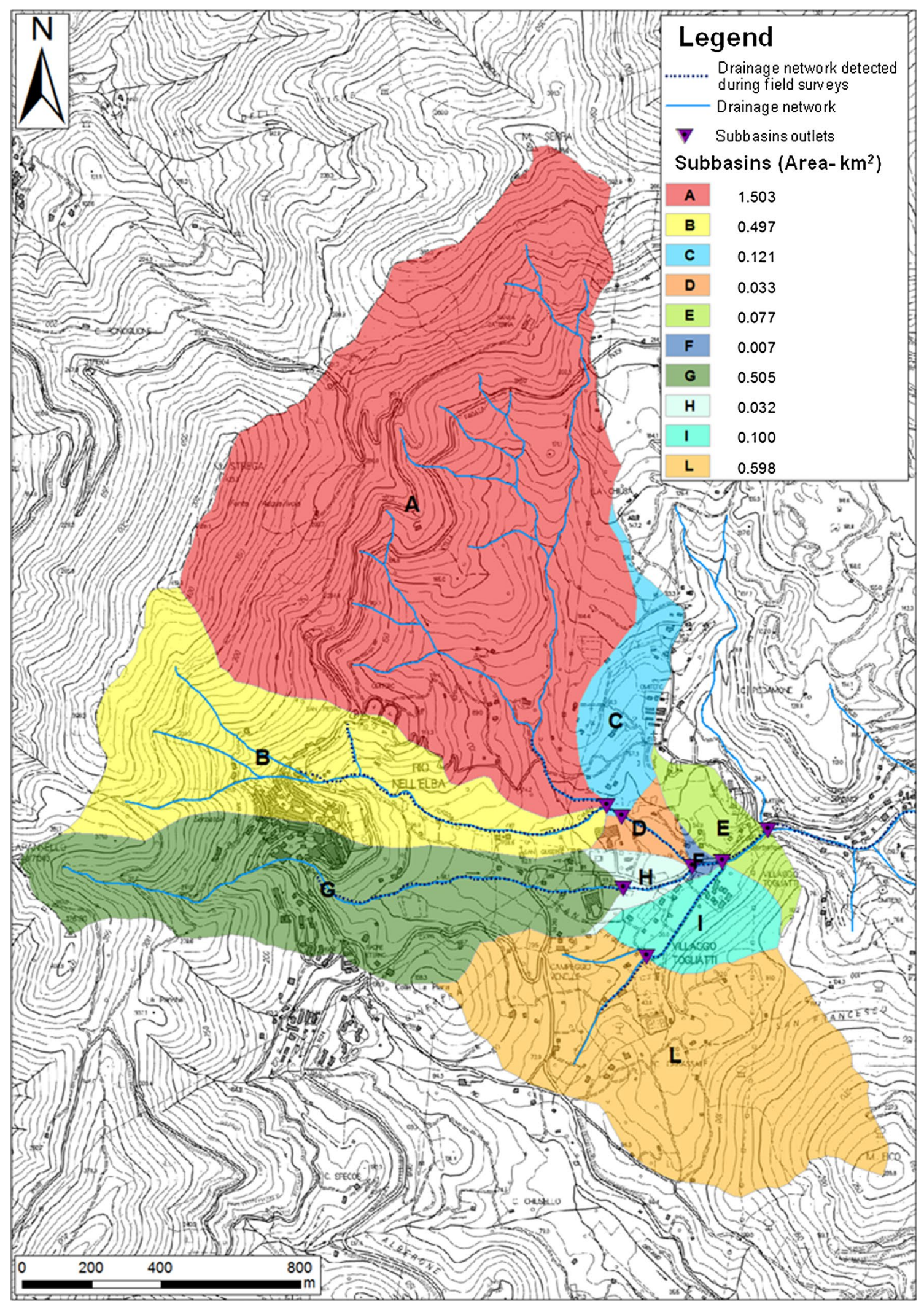

Fig. 12 Subbasins and their respective outlets located upstream of the sinkhole-prone area 


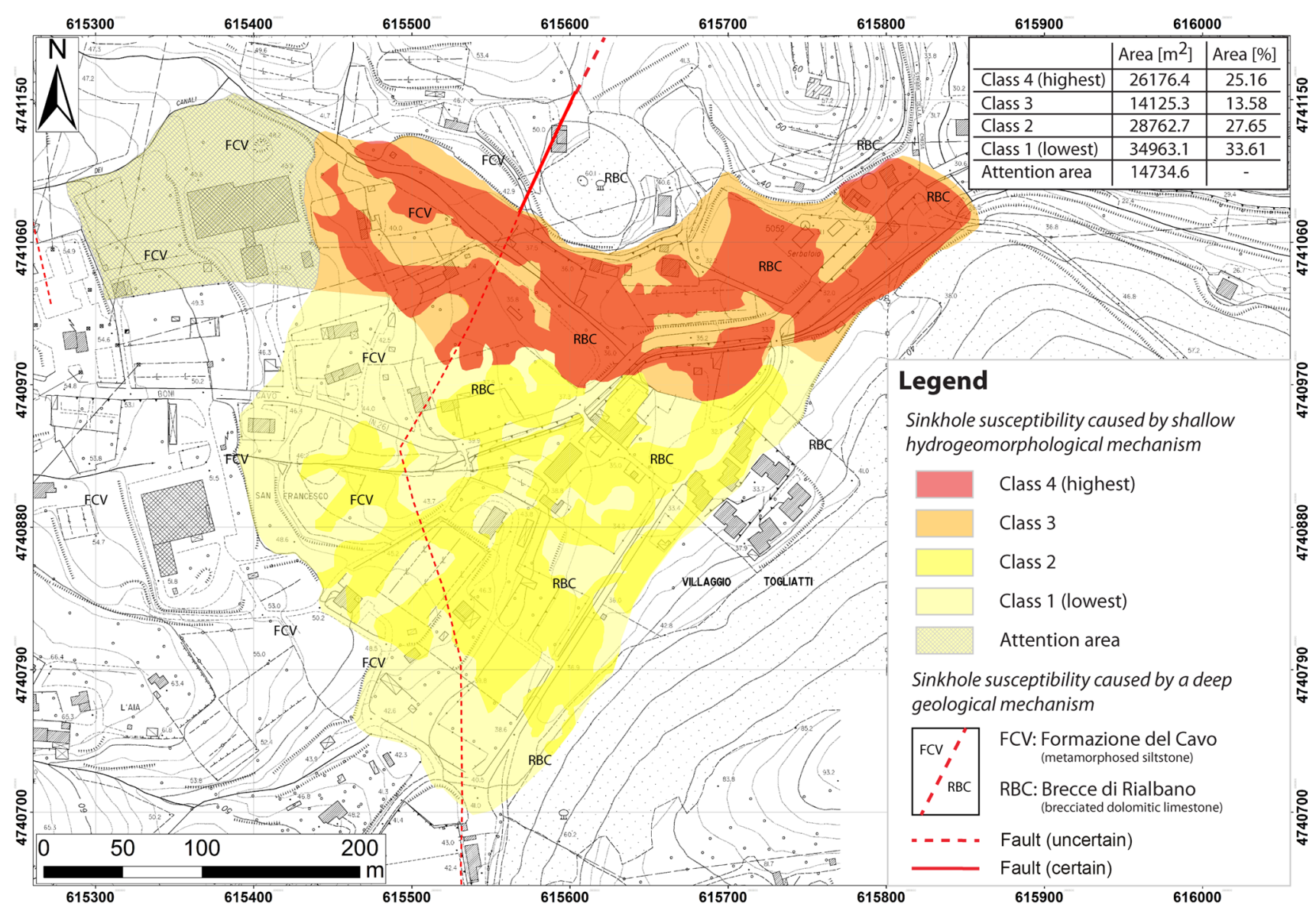

Fig. 13 Sinkhole susceptibility map: colours from red (class 4-highest susceptibility) to light yellow (class 1-lowest susceptibility) indicate the areas where sinkholes could occur because of shallow hydrogeomorphological mechanisms. The extension of the different areas $\left(\mathrm{m}^{2}\right.$ and percentage) is listed in the table. The rock substratum is indicated as either FCV (Formazione del Cavo) and RBC (Brecce di Rialbano) (identified through geoelectric surveys and historical and surface runoff analyses).

Consequently, the following four classes of susceptibility have been mapped (Fig. 13):

- Red Area-Class 4: covers $25.16 \%$ of the area and is the most prone to sinkholes because of the presence of subsoil lenticular bodies and a high hydraulic load (northern subbasin).

- Orange Area-Class 3: in $13.58 \%$ of the area, the integrated geophysical surveys did not identify any subsoil lenticular bodies, but the hydraulic load is very high (northern subbasin).

- Yellow Area-Class 2: in $27.65 \%$ of the area, the integrated geophysical surveys identified subsoil lenticular bodies, and the hydraulic load is limited (southern subbasin).

- Light Yellow Area-Class 1: in 33.61\% of the area, the integrated geophysical surveys did not identify sub- soil lenticular bodies, and the hydraulic load is limited (southern subbasin).

Finally, outside the sinkhole-prone zone an "attention area" (Fig. 13) has been indicated: this area is characterized by poor management of the superficial waters. Taking into account the location of this area (within the northern hydrographic subbasin, above old milling features and close to the sinkhole-prone areas), in the absence of corrective measures, sinkholes may develop in the future.

\section{Conclusions}

The Il Piano region has been affected by a series of sinkholes localized within a small area. The study of historical maps and aerial photographs has not identified possible forms ascribable to older sinkholes, although the occurrence of past and undiscovered events cannot be excluded. Field 
surveys and historical research highlighted the presence of a complex network of artificial ditches used to power water mills until the middle of the twentieth century. Because of the fast development of the study area, these channels are now abandoned if not disrupted, although they still constitute an important drainage network capable of diverting significant quantities of water, often at a subsuperficial level.

Hydrogeological tests and monitoring showed that the region is characterized by two unconfined, non-communicating aquifers separated by an impermeable layer of predominantly clay. The upper aquifer is scarcely exploited and is identified within a heterogeneous sedimentary cover with permeable bodies (corresponding to ancient riverbeds and buried ditches) and finer and more cohesive sediments. The deeper aquifer is more heavily exploited and is found within the karst limestone of the Rialbano Breccia. The extension and permeability of this aquifer are such that the lowering of the water table is limited in both depth and areal extent and, most importantly, does not affect the upper sedimentary cover. For this reason, a cover collapse mechanism in which the sediments are drawn into karst cavities due to an increase in the hydraulic gradient cannot be considered likely.

As a consequence, the triggering mechanism was associated with superficial processes that involve a relatively fast and possibly pressurized water flow within buried but shallow permeable bodies, which cause ravelling and erosion of the finer sediments and may eventually evolve into small and sudden sinkholes entirely localized within the deposits. The removed material can then be transported through the loose sediments and cracks and end up in the riverbeds of nearby streams or in deeper karst cavities. Therefore, the karst bedrock plays a passive role, if any. It is thought that the occurrence of fast, pressurized water flows is due to heavy rainfall events and especially to the extension of the subbasins of the Il Piano catchment. In particular, the northern subbasins are characterized by large areal extents and short and narrow streams; given the documented infiltration process, it is hypothesized that subsuperficial ravelling processes may occur mainly downstream of the larger basins. This hypothesis corresponds to the observation of the locations of the sinkholes and explains why no sinkholes have been recorded yet in the southern part of the region, where the geological conditions and water pumping activities are basically equivalent to the northern part of the region. According to this conceptual model, a sinkhole susceptibility map was produced for the area.

Although the occurrence of cover collapse sinkholes directly involving water pumping and karst cavities cannot be completely excluded, it must be considered a secondary mechanism.

All considered, the predisposing factors identified in this work are geological (related to the presence of heterogeneous deposits), geomorphological (the extension of the subbasins) and anthropogenic (the presence of buried channels). The triggering factors are rainfall events that, as described above, can be intense. Uncontrolled domestic water diversions or inflows and a poorly maintained natural and artificial drainage network aggravate the sinkhole risk.

Acknowledgements The authors are grateful to Brilli Mirco, Claudio Benucci, Maurizio Micheli, Fabio Baldi, Michele Muti and Massimo Caldori of the ASA s.p.a., the society responsible for the drinking water on Elba Island, for allowing piezometric monitoring and pumping tests in their wells. We also wish to thank Lorenzo Giardi and Niccolò Galfo for their fieldwork support.

Open Access This article is distributed under the terms of the Creative Commons Attribution 4.0 International License (http://creativecommons.org/licenses/by/4.0/), which permits unrestricted use, distribution, and reproduction in any medium, provided you give appropriate credit to the original author(s) and the source, provide a link to the Creative Commons license, and indicate if changes were made.

\section{References}

Argentieri A, Carluccio R, Cecchini F, Chiappini M, De Ritis R, Di Filippo M, Di Nezza M, Marchetti M, Margottini S, Materni V, Meloni F, Nardi A, Rotella G, Sapia V, Venuti A (2015) Early stage sinkhole formation in the Acque Albule basinof central Italy from geophysical and geochemical observation. Eng Geol 191:36-47. https://doi.org/10.1016/j.enggeo.2015.03.010

Beck BF, Sinclair WC (1986) Sinkholes in Florida: an introduction. Florida Sinkhole Research Institute Report, pp 85-86

Bishop I, Styles P, Emsley SJ, Ferguson NS (1997) The detection of cavities using the microgravity techniques: case histories from mining and karstic environments. Eng Geol Spec Publ 12:153166. https://doi.org/10.1144/GSL.ENG.1997.012.01.13

Bortolotti V, Fazzuoli M, Pandeli E, Principi G, Babbini A, Corti S (2001) Geology of Central and Eastern Elba Island, Italy. Ofioliti 26(2a):97-150

Butler DK (1984) Microgravimetric and gravity gradient techniques for detection of subsurface cavities. Geophysics 49:1084-1096

Caramanna G, Ciotoli G, Nisio S (2008) A review of natural sinkhole phenomena in Italian plain areas. Nat Hazards 45(2):145-172

Cardarelli E, Cercato M, De Donno G, Di Filippo G (2014) Detection and imaging of piping sinkholes by integrated geophysical methods. Near Surface Geophys 12:439-450

CASTORE Project, Tuscany Region and State Archives of Tuscany (2016) Available online: http://web.rete.toscana.it/castoreapp

Cooper HH, Jacob CE (1946) A generalized graphical method for evaluating formation constants and summarizing well field history. Am Geophys Union Trans 27:526-534

Cramer H (1941) Die Systematik der karstdolinen. Neues Jahrbuch für Mineralogie, Geologie und Palaontologie 85:293-382 (In German)

Del Soldato M, Segoni S, De Vita P, Pazzi V, Tofani V, Moretti S (2016) Thickness model of pyroclastic soils along mountain slopes of Campania (southern Italy). In: Aversa et al (eds) Landslides and engineered slopes. Experience, theory and practice. Associazione Geotecnica Italaiana, Rome, Italy. ISBN:978-1-138-02988-0

Del Ventisette C, Casagli N, Fortuny-Guasch J, Tarchi D (2012) Ruinon landslide (Valfurva, Italy) activity in relation to rainfall by means of GBInSAR monitoring. Landslides 9(4):497-509 
Di Nezza M, Cecchini F, Margottini S, Di Filippo M (2015) Deeper geological and structural settings of Acque Albule Basin (Rome, Latium). $3^{\circ}$ Workshop internazionale: Voragini in Italia. I Sinkholes e le cavità sotterranee: ricerca storica metodi di studio e d'intervento. Roma 8 Maggio 2014, Roma. Mem. Descr. Carta Geol. It, pp 267-272. ISSN: 0536-0242

Dunne T (1990) Hydrology, mechanics, and geomorphic implications of erosion by subsurface flow. In: Higgins CG, Coates DR (eds) Groundwater geomorphology; the role of subsurface water in earth-surface processes and landforms. The Geological Society of America, Special Paper vol 252, pp 1-28

Ezersky M (2008) Geoelectric structure of the Ein Gedi sinkhole occurrence site at the Dead Sea shore in Israel. J Appl Geophys 64:56-69

Ferreli L, Guerrieri L, Nisio S, Vita L, Vittori E (2004) Relations among seismogenic structures, earthquakes and sinkhole phenomena: a methodological approach in the Apennines (Italy). In: Proceedings of the 32 nd international geological congress, Firenze, Italy

Giampaolo V, Capozzoli L, Grimaldi S, Rizzo E (2016) Sinkhole risk assessment by ERT: the case study of Sirino Lake. Geomorphology 253:1-9

Griffin WP (1949) Residual gravity in theory and practice. Geophysics 14:39-56

Gutiérrez F, Guerrero J, Lucha P (2008) A genetic classification of sinkholes illustrated from evaporite paleokarst exposures in Spain. Environ Geol 53:993-1006

Higgins CG, Schoner C (1993) Sinkholes formed by piping into buried channels. Geomorphology 20(3-4):307-312

IGM (Military Geographic Institute) (2016) Available online: http:// www.igmi.org

Intrieri E, Gigli G, Nocentini M, Lombardi L, Mugnai F, Fidolini F, Casagli N (2015) Sinkhole monitoring and early warning: an experimental and successful GB-InSAR application. Geomorphology 241:304-314

Jones CE, Blom RG (2014) Bayou Corne, Louisiana, sinkhole: precursory deformation measured by radar interferometry. Geology 42:111-114

Lane JW, White EA, Steele GV, Cannia JC (2008) Estimation of bedrock depth using the horizontal-to-vertical (H/V) ambient-noise seismic method. In: Proceedings of the 21st EEGS symposium on the application of geophysics to engineering and environmental problems, Philadelphia, USA, pp 490-502

Lee EJ, Shin SY, Ko BC, Chang C (2016) Early sinkhole detection using a drone-based thermal camera and image processing. Infrared Phys Technol 78:223-232

Lotti A, Saccorotti G, Fiaschi A, Matassoni L, Gigli G, Pazzi V, Casagli N (2015) Seismic monitoring of rockslide: the Torgiovannetto quarry (Central Apennines, Italy). In: Lollino G, et al (eds) Engineering geology for society and territory, vol. 2. Springer International Publishing, Switzerland, pp 1537-1540. https://doi. org/10.1007/978-3-319-09057-3 272

Marr JC (1955) Sinkholes in irrigated fields. Calif Agric 9(11):6-7
Nisio S (2008) I sinkholes: problemi terminologici, meccanismi genetici, classificazione. In: Nisio S (ed) Memorie descrittive della carta geologica d'Italia LXXXV, pp 17-32 (In Italian)

Nisio S, Caramanna G, Ciotoli G (2007) Sinkholes in Italy: first results on the inventory and analysis. Geol Soc Lond Spec Publ 279:23-45

Nof RN, Baer G, Ziv A, Raz E, Atzori S, Salvi S (2013) Sinkhole precursors along the Dead Sea, Israel, revealed by SAR interferometry. Geology 41:1019-1022

Pazzi V, Tapete D, Cappuccini L, Fanti R (2016) An electric and electromagnetic geophysical approach for subsurface investigation of anthropogenic mounds in an urban environment. Geomorphology 273:335-347

Pazzi V, Tanteri L, Bicocchi G, Caselli A, D’Ambosio M, Fanti R (2017a) H/V technique for the rapid detection of landslide slip surface(s): assessment of the optimized measurements spatial distribution. In: Mikos M, Tiwari B, Yin Y, Sassa K (eds) Advancing culture of living with landslides, vol. 2-advances in landslide science. Springer, Switzerland, 335-343, https://doi. org/10.1007/978-3-319-53498-5_38

Pazzi V, Tanteri L, Bicocchi G, D’Ambrosio M, Caselli A, Fanti R (2017b) H/V measurements as an effective tool for the reliable detection of landslide slip surfaces: case studies of Castagnola (La Spezia, Italy) and Roccalbegna (Grosseto, Italy). Phys Chem Earth 98:136-153. https://doi.org/10.1016/j.pce.2016.10.014

Pierotti P (1993) La valle dei mulini. In: Pacini (ed) Ospedaletto (PI), Italy. (In Italian)

Piro S, Tsourlos PI, Tsokas GN (2001) Cavity detection employing advanced geophysical techniques: a case study. Eur J Environ Eng Geophys 6:3-31

SESAME (2004) Guidelines for the implementation of the H/V spectral ratio technique on ambient vibrations. Measurements, processing and interpretation. SESAME European research project, WP12Deliverable D23.12, European Commission-Research General Directorate, Project No. EVG1-CT-2000-00026 SESAME

Snyder SW, Evans MW, Hines AC, Compton JS (1989) Seismic expression of solution collapse features from the Florida Platform. In: Engineering and Environmental Impacts of Sinkholes and Karst. In: Proceedings of the 3rd multidisciplinary conference on sinkholes and the engineering and environmental impacts of Karst, St. Petersburg Beach, Florida, USA, pp 281-298

Strini A (2004) Il fenomeno "occhi pollini” della Brianza (Lombardia, Italia). Caratteristiche e genesi di cavità in depositi quaternari. Quaderni di Geologia Applicata 11(1):83-99 (In Italian)

Tuscany Region (2016) Available online: http://www.regione.toscana.it

Waltham T, Bell FG, Culshaw MG (2005) Sinkholes and subsidence: Karst and cavernous rocks in engineering and construction. Springer, Berlin, p 382. https://doi.org/10.1007/b138363

White WB (1988) Geomorphology and hydrology of karst terrains. Oxford University Press, New York, p 464

Williams P (2003) Dolines. Encyclopedia of caves and karst science. Fitzroy Dearborn, New York, pp 304-310 